Agnieszka Rypel ${ }^{1}$

Uniwersytet Kazimierza Wielkiego w Bydgoszczy

DOI: https://doi.org/10.26881/jsr.2021.16.13

\title{
MOJA POLSKA - MOJA ANGLIA. ROZWAŻANIA NA MARGINESIE LEKTURY MARCINA KOZERY MARII DĄBROWSKIEJ W KONTEKŚCIE WSPÓŁCZESNEJ EMIGRACJI DO WIELKIEJ BRYTANII
}

Każdy wie od poczatku, kim jest, a ja się muszę tak męczyć. (Marcin Kozera; Dąbrowska 1972, s. 61)

Opowiadanie Marii Dąbrowskiej zatytułowane Marcin Kozera ukazało się w 1927 r. Wpisywało się w ówczesny program wychowania patriotycznego, choć głoszone w tekście wartości straciły nieco na wymowie, kiedy w latach 30 . XX w., po wprowadzeniu tzw. Jędrzejewiczowskiej reformy oświaty, zaczęto kłaść nacisk przede wszystkim na wychowanie propaństwowe. W oficjalnym kanonie lektur szkolnych Marcin Kozera znalazł się dopiero po blisko 45 latach od daty pierwszego wydania. W programach języka polskiego z lat 1971-1985 (Por. Program nauczania... 1971, s. 46) zalecano go jako lekturę obowiązkową, a potem uzupełniającą dla klasy VI. Paradoksalnie największą poczytność (bo wymuszoną obligatoryjnością w szkole) opowiadanie miało więc w tym okresie istnienia PRL, w którym nie było problemu masowej emigracji - czy to politycznej, czy to zarobkowej; a kiedy po 1981 r. problem ten się pojawił, nie wolno było pisać o nim w szkolnych podręcznikach. Oficjalny przekaz pomijał też lub wypaczał rolę emigracji powojennej, zwłaszcza tej osiadłej w Wielkiej Brytanii. Pewien margines, nieco folklorystyczny, zostawiono dla starej Polonii amerykańskiej, która wyjechała za chlebem na długo, zanim w Polsce doszło do zmian ustrojowych. W jednej z czytanek szkolnych z lat 70. pojawiły się także odwiedzające kraj przodków dzieci - potomkowie Polaków, którzy na początku lat 20. masowo zatrudniali się we francuskich i belgijskich kopalniach.

Zgodnie z silnie zakorzenionym w polskiej tradycji edukacyjnej wzorem kulturowym uczeń czytający opowiadanie Dąbrowskiej postrzegał życie na ob-

${ }^{1}$ a.rypel@ukw.edu.pl, https://orcid.org/0000-0003-2379-7318 
czyźnie przede wszystkim przez pryzmat Wielkiej Emigracji. Tak jak w literaturze romantycznej wyidealizowany był obraz Polski, tak w edukacji polonistycznej uwznioślano obraz emigranta - a więc człowieka niemającego żadnych problemów tożsamościowych, niezmiennie związanego z ojczyzną, którą postrzegano jako stały punkt odniesienia w obcym, nierzadko wrogim świecie. Więzi z polskością mogły się osłabić, ale nigdy zerwać, jak dowodzi choćby przykład Skawińskiego z Sienkiewiczowskiego Latarnika. Taki spetryfikowany obraz uchodźcy - stęsknionego wygnańca bez prawa powrotu do ukochanej ojczyzny - stał się częścią narodowej celebry i, podobnie jak problemy starych Polonusów czy powojennych emigrantów, znacznie odbiegał od codziennych doświadczeń uczniów oraz ich rodzin żyjących w latach 70. i 80. XX w.

Opowieść o tytułowym Marcinie Kozerze, mieszkającym w Londynie chłop$\mathrm{cu}$, który przeżywa kryzys tożsamościowy, zniknęła z edukacji polonistycznej właśnie wtedy, kiedy za granicę zaczęło emigrować coraz więcej Polaków. Zjawisko to nasiliło się po 2004 r., gdy Unia Europejska otworzyła swoje rynki pracy dla nowych krajów członkowskich. Obecnie w Anglii, którą Marcin długo uważał za swoją jedyną ojczyznę, mieszka według oficjalnych danych brytyjskiego urzędu statystycznego (ONS) ok. 815 tys. Polaków. W szczycie masowej emigracji przypadającym na koniec $2017 \mathrm{r}$. było ich 1,021 $\mathrm{mln}^{2}$ (w rzeczywistości mogło być ich znacznie więcej: według niektórych szacunków 1,5 mln, a nawet okresowo $2 \mathrm{mln}$ ). W związku z brexitem liczba emigrantów z Polski mieszkających w Wielkiej Brytanii się zmniejszyła. Dane z połowy 2020 r., a więc już po oficjalnym wystąpieniu tego kraju z Unii Europejskiej (1.01.2020 r.), wskazują, że Wyspy opuściło 176 tys. naszych rodaków. Jednocześnie, zgodnie z ustaleniami ONS, do 30 września 2020 r. 773 tysiące Polaków złożyło podanie o stały pobyt w Zjednoczonym Królestwie. Istotne jest, że po ogłoszeniu wyników przeprowadzonego w 2016 r. referendum w sprawie wyjścia UK z Unii Europejskiej tylko w ciągu dwóch pierwszych lat aż 23,586 tys. Polaków wystąpiło o brytyjskie obywatelstwo. Oddzielną, nieodnotowaną w przytoczonych statystykach grupą są Polacy, którzy żyją w Wielkiej Brytanii dostatecznie długo, aby nie ubiegać się obecnie o prawo stałego pobytu, oraz potomkowie starej, powojennej emigracji posiadający brytyjskie obywatelstwo już od urodzenia.

Przedstawione dane poświadczają, że w Wielkiej Brytanii mieszka (i wiele wskazuje na to, że nadal będzie mieszkać) bardzo liczna grupa Polaków. Szacuje się, że w Zjednoczonym Królestwie żyje obecnie 73 tys. obywateli Polski, którzy urodzili się już w nowym kraju osiedlenia ich rodziców. Zarówno dzieci, które przyszły na świat za granicą, jak i te, które we wczesnym dzieciństwie przyjechały do Anglii wraz z rodzicami - a ponadto i te, które narodzą się poza

${ }^{2}$ Wskazane w tym akapicie dane statystyczne cytuję za: Bielecki 2020. Dostęp do wszystkich źródeł internetowych: 25.04.2021. 
Polską w przyszłości - z dużym prawdopodobieństwem będą musiały w większym lub mniejszym stopniu zmierzyć się z problemem własnej tożsamości narodowej³ Problem ten dotyczy także dzieci, które całe dotychczasowe świadome życie spędziły w Wielkiej Brytanii, a teraz wraz z rodzicami, często bardzo niechętnie, przyjechały (bo przecież nie wróciły) do kraju przodków. Polscy rodzice - emigranci lub reemigranci -niejednokrotnie przyznają, że dopiero po latach zaczęli zdawać sobie sprawę z ogromnych trudności, z jakimi zmagały się ich dzieci próbujące określić, kim właściwie są lub kim chcą być - Anglikami czy Polakami. Dorośli często nie uświadamiają sobie, w jaki sposób przebiega/przebiegał proces budowania własnej tożsamości narodowej młodych ludzi oraz jak bardzo świadomość ta jest złożona, wieloaspektowa, niepoddająca się prostym dychotomicznym podziałom. Wiele dzieci mogłoby z pewnością powiedzieć jak Marcin Kozera: „Dlaczego - mówił sobie - u wszystkich jest tak zwyczajnie? Każdy wie od początku, kim jest, a ja się muszę tak męczyć”" (Dąbrowska 1972, s. 61).

Celem artykułu jest przedstawienie problematyki opowiadania Marii Dąbrowskiej i sprawdzenie, w jakim zakresie mogłoby ono zostać wykorzystane we współczesnej edukacji polonistycznej w szkołach, do których uczęszczają dzieci Polaków mieszkających za granicą, nie tylko w Wielkiej Brytanii (także w Niemczech, Holandii, Norwegii, USA), choć to właśnie ten kraj ze względu na miejsce akcji utworu będzie stanowił punkt odniesienia do podjętych $\mathrm{w}$ artykule rozważań. Nie bez znaczenia jest również fakt, iż to właśnie Polacy mieszkający w Zjednoczonym Królestwie są najbardziej spośród pozostałych migrantów zakorzenieni w kraju osiedlenia - zarówno ze względu na długość pobytu, rodzinę i znajomych, jak i z powodu posiadanych nieruchomości. Postaramy się sprawdzić, czy lektura napisanego blisko sto lat temu Marcina Kozery może posłużyć dzisiejszym młodym polskim mieszkańcom Anglii jako źródło inspiracji i bodziec do refleksji nad własną tożsamością narodową.

Akcja opowiadania toczy się w Londynie, tuż przed wybuchem I wojny światowej, w 1913 r. Tego samego roku Dąbrowska przebywała w stolicy Anglii jako stypendystka Towarzystwa Kooperatystów. W swoim tekście nawiązywała zatem do obserwacji poczynionych wówczas w środowisku polskiej emigracji. Pisarka odnosi się do rzeczywistych warunków życia londyńskiej Polonii oraz panujących

${ }^{3}$ W Wielkiej Brytanii, gdzie migracja w porównaniu z innymi krajami (Niemcami, Holandią i Norwegią) ma najbardziej osiadły charakter, obserwujemy na przestrzeni ostatnich lat naturalny proces przechodzenia migrantów do kolejnych grup wiekowych. Osoby przed 35. r.ż. stanowią już tylko połowę populacji Polaków żyjących w Zjednoczonym Królestwie Może to świadczyć o tym, że potencjalnie coraz więcej osób będzie mierzyć się z problemami tożsamościowymi narastającymi w miarę stopniowego, długotrwałego przystosowania się bądź odrzucania kultury i stylu życia kraju przyjmującego (zob. Chmielewska, Panuciak, Strzelecki 2019, s. 9). 
w niej stosunków. Kim zatem byli żyjący w Londynie Polacy? Większą ich część stanowili robotnicy, mieszkający i pracujący w przemysłowej dzielnicy metropolii:

Otóż w Londynie, na uboczu, w hałaśliwej dzielnicy biedaków jest plac, który się nazywa Charles Square. Miejsce to nie jest wesołe, bo domy, które tam stoją naokoło, są prawie czarne. A gdy wiatr rozpościera nad placem dymy fabryk, niebo nad nim staje się także czarne. [...] Pamiętam za to, że w pobliżu tego placu mieszkało wtedy dużo Polaków [...] Byli to przeważnie robotnicy, którzy pracowali w londyńskich fabrykach od wielu lat (Dąbrowska 1972, s. 7-8).

Polacy mieszkający w Anglii przedstawiani są zatem jako ludzie niewykształceni, wykonujący pracę fizyczną, żyjący w nie najlepszych warunkach w ubogiej, ponurej dzielnicy wielkiego miasta. Do Anglii przyjechali przeważnie za chlebem. Niektórzy - tak jak ojciec Marcina, Mateusz Kozera - dorobiwszy się, planują powrót do kraju. Są też tacy, którzy wyjechali z Polski w trosce o bezpieczeństwo swoje i bliskich, uciekając przed represjami władz zaborczych: „Wielu z tych ludzi - to byli wygnańcy, którzy nie mogli wrócić do Polski, jak długo była w jarzmie niewoli” (Dąbrowska 1972, s. 56).

Współcześni emigranci, niezależnie od powodu opuszczenia Polski, mogą w każdej chwili wrócić do kraju, nie istnieją bowiem żadne przeszkody natury politycznej, niemniej jednak spora grupa Polaków nie opuszcza kraju osiedlenia z przyczyn ekonomicznych. Według statystyk polskiego Ministerstwa Spraw Wewnętrznych na pozostanie w Wielkiej Brytanii zdecydowali się przede wszystkim emigranci zaliczani do tzw. straconego pokolenia, czyli osoby, które choć nie zrobiły na emigracji kariery, to nie powracają do Polski z braku dostatecznego kapitału i wykształcenia zapewniającego im godziwe warunki życia w ojczyźnie. Ludzie ci korzystają często z usług polskich biur pośrednictwa i na ogół na ich zlecenie podejmują się prac dorywczych, często też korzystają z różnego rodzaju zasiłków. Wielu Polaków, zwłaszcza tych nieznających języka angielskiego i niemających wykształcenia ani kwalifikacji zawodowych, obejmuje posady wprawdzie niskopłatne, ale z polskiej perspektywy ciągle opłacalne. Jak wynika z ostatniego raportu zlecanego co dwa lata przez Departament Statystyki Narodowego Banku Polskiego, wśród emigrantów pracujących w Wielkiej Brytanii w 2018 r. najwyższy odsetek (42\%) stanowiły jednak osoby zatrudnione jako wykwalifikowani robotnicy i rzemieślnicy (krawcowe, fryzjerki, hydraulicy, budowlańcy itp.). Wiele jest też osób zatrudnionych w zawodach związanych z opieką nad osobami starszymi lub pomocą $\mathrm{w}$ domu, co również wymaga pewnego poziomu kwalifikacji lub doświadczenia. Trzeba też podkreślić relatywnie duży odsetek emigrantów pracujących jako specjaliści (9\%) oraz menedżerowie (13\%). Z przedstawionych danych wynika, że choć Polacy znacznie częściej wykonują bardziej prestiżowe 
prace wymagające biegłości, kompetencji i wykształcenia, to nadal pozostają poza angielską klasą średnią (Chmielewska, Panuciak, Strzelecki 2019, s. 18). Osoby już należące do tej sfery stanowią zdecydowaną mniejszość, podobnie jak to było w czasie, w którym toczy się akcja opowiadania Dąbrowskiej. Wśród Polaków mieszkających w Londynie w przededniu wybuchu I wojny światowej również żyje tylko niewielka grupa ludzi ,nie naszych”, należących do wyższej klasy społecznej - zamożnych, wykształconych i mieszkających w dobrych dzielnicach: „Ludzie zalegali gromadami wszystkie kąty. I to nie tylko nasi ludzie z dzielnicy robotniczej! Przybyli także polscy studenci, niektórzy przyjechali aż z Oksfordu. Pojawili się nieznajomi panowie i panie z zachodniej dzielnicy Londynu, poodziewani w futra i pióra" (Dąbrowska 1972, s. 49).

Młodzi emigranci lub ich urodzone w Anglii dzieci muszą zatem odnaleźć balans między wciąż stosunkowo niską pozycją społeczno-ekonomiczną swoich rodzin a własnymi aspiracjami i możliwościami. Ciągle jeszcze wielu Polaków mieszkających w Wielkiej Brytanii określa siebie jako osoby zatrudnione poniżej swoich kwalifikacji ${ }^{4}$, co wyraźnie wpływa na ich sposób postrzegania dalszej ścieżki zawodowej oraz planów na przyszłość, a ponadto na poczucie własnej wartości. Lektura opowiadania Marii Dąbrowskiej może zatem skłonić współczesnych młodych migrantów oraz ich potomków do stawiania pytań o to, w jakim stopniu i w jaki sposób zmieniła się pozycja Polaków w strukturze społecznej i ekonomicznej Wielkiej Brytanii? Jaki kierunek mają obecne przemiany? Jak pozycja rodzin, z których się wywodzą, wpływa na ich samoocenę w konfrontacji z resztą wielokulturowego społeczeństwa? Czy ich własna mobilność

${ }^{4}$ Co jednak istotne, odsetek ten regularnie się obniża. Jeszcze 4 lata wcześniej pracę poniżej kwalifikacji deklarowało 40-50\% respondentów; w ostatnim badaniu z 2018 r. było to już tylko 28-36\%. (Chmielewska, Panuciak, Strzelecki 2019, s. 19).

${ }^{5} \mathrm{~W}$ opublikowanym w $2006 \mathrm{r}$. raporcie Polscy migranci w Londynie - klasa spoteczna i etniczność stwierdzono, że ok. 3/4 migrantów przybyłych do Wielkiej Brytanii w ciągu 2 lat po akcie akcesyjnym wykonywało tzw. prace rutynowe (ang. semi-routine, routine jobs), niewymagające kwalifikacji, a często nawet znajomości języka angielskiego. Fakt ten bardzo wyraźnie wiąże pochodzenie narodowe z pozycją społeczną i ekonomiczną Polaków w kraju osiedlenia, na co wyraźnie wskazuje porównanie wyników badań $\mathrm{z}$ badaniami $\mathrm{w}$ innych populacjach. Otóż profesjonaliści oraz menedżerowie stanowią $68 \%$ wśród migrantów anglojęzycznych, $42 \%$ z innych krajów akcesyjnych i 10\% z krajów akcesyjnych, które do Unii Europejskiej wstąpily, tak jak Polska, w 2004 r. (Cypr, Czechy, Estonia, Litwa, Łotwa, Słowacja, Słowenia, Węgry). Ponadto polscy emigranci, którzy przybyli do Zjednoczonego Królestwa w pierwszej fali masowej migracji, w przeciwieństwie do migrantów z pozostałych krajów akcesyjnych w bardzo niewielkim stopniu skorzystali w sensie finansowych ze swego, niejednokrotnie bardzo dobrego, wykształcenia. Z drugiej strony zauważyć można, że Polacy, którzy osiedlili się w Londynie między 1991 a 2001 r. znacznie częściej pracowali w zawodach wyspecjalizowanych i zajmowali się zarządzaniem (zob. Eade, Drinkwater, Garapich 2006, s. 6). 
społeczna (lub jej brak) w jakiś sposób wiąże się z pochodzeniem narodowym? I wreszcie: jak obecnie funkcjonują skupiska Polaków? Jak mieszkanie w tej samej dzielnicy, wpływa na ich relacje między polską i brytyjską społecznością? Jakie czynniki spajają różne grupy Polaków?

W opowiadaniu Dąbrowskiej różnice społeczno-ekonomiczne sprawiają, że związki między lepiej sytuowanymi i wykształconymi emigrantami a robotnikami są dość luźne. Przedstawiciele nielicznej polskiej klasy średniej zjawiają się w dzielnicy robotniczej rzadko; okazją do spotkania są bożonarodzeniowe jasełka wystawiane przez dzieci z polskiej szkoły. Oba te środowiska łączy zatem, choć sporadycznie, poczucie wspólnoty narodowej, które manifestuje się poprzez silne związki z tradycjami o rodowodzie katolickim, przywiązanie do tych samych symboli, pieśni i tańców narodowych oraz stosunek do doświadczeń historycznych. Przejawiająca się w ten sposób tożsamość narodowa jest więc czynnikiem spajającym różne grupy Polaków, ponad podziałami klasowymi. A jak jest obecnie? Jak dziś wygląda integracja środowisk polonijnych?

Z problemem mobilności społecznej wiąże się także kwestia prestiżu i atrakcyjności obu kultur. Zachodzące stopniowo zmiany w postrzeganiu przez Europy ojczyzn, zdaniem Andrzeja Szpocińskiego,

nie zmieniły w niczym funkcjonującej co najmniej od stu pięćdziesięciu lat hierarchii kultur. Tak jak pięćdziesiąt i sto lat temu najwyższe pozycje na skali prestiżu zajmuje pięć kultur centralnych (francuska - niepodważalna pozycja lidera, niemiecka, angielska, włoska i rosyjska). Dalej mamy kultury pośrednie (flamandzka i niderlandzka, skandynawska, hiszpańska i amerykańska), a wreszcie kultury peryferyjne (Szpociński 2002, s. 99; zob. też: Winnicki 2017).

Wprawdzie kultura polska, podobnie jak kultura czeska, wyróżnia się na tle kultur pozostałych krajów Europy Środkowej i Wschodniej, niemniej jednak ciągle aspiruje do tego, aby wyjść z kręgu peryferyjności. Podobne aspiracje ma Polska również w aspekcie ekonomicznym i gospodarczym. Nie jest wprawdzie potęgą, lecz w szybkim tempie nadgania zapóźnienia cywilizacyjne, na skutek czego znacznie wzrasta poziom życia jej mieszkańców. W czasach, kiedy Marcin Kozera pokazywał Londyn swej polskiej przyjaciółce Krysi, różnice w rozwoju Polski i Anglii były ogromne. W opowiadaniu Dąbrowskiej fakt ten został wyraźnie podkreślony dzięki kontrastowemu obrazowaniu Londynu i Łowicza oraz krajobrazu uznanego za typowy dla naszego kraju:

Lo n d y

- zabudowa: ulice (rozmaite, ogromne), aleje (wspaniałe, dtugie), mosty (przerzucaty się przez rzeke, jeden za drugim), parlament (olbrzymi 
rozłożysty gmach), opactwo westminsterskie (najwspanialszy kościót majestatyczny jak góra, a jednocześnie tak lekko zrobiony, że można by pomyśleć, że z koronki. I też cały byt w misternych kolcach, jakby w czarnych promieniach), katedra (wspaniała), reklamy (naokoło nad wszystkimi domami sterczaty wszędzie olbrzymie reklamy handlowe wsparte na dragach), okna domów (błyszczały);

- środki lokomocji: autobusy piętrowe (byto ich tak dużo, że wypetniaty cała jezdnię i zaledwie mogły się poruszać), tramwaje (chodza tam tylko na przedmieściach), samochody, automobile, statki (ogromne statki sunace przez cicha wodę w chmurach dymu);

- ruch: przez chodniki sunęli ludzie ogromnymi ttumami;

- odgłosy: gwizd i ryk sygnałów automobilowych, krzyk ulicznych sprzedawców, toskot motorów w samochodach;

- przyroda: Roztoczyly się przed ich oczami wspaniate aleje, prawie że puste. Staty na nich drzewa w złocistych liściach - a wzdtuż jednej alei płynęta $w$ szerokich wałach z kamienia prześliczna rzeka. Woda $w$ niej mieniła się jak tęcza - i powietrze nad nia mieniło się tak samo, nasycone mgła i blaskami słońca (Dąbrowska 1972, s. 22-24), na środku placu rosty drzewa, zielony skwer otoczony sztachetkami (Dąbrowska 1972, s. 8).

P o l s k a

- Łowicz: Tatuś mówi, że tam jest rzeka. I jakiś pałac jest. Kościół też jest. Tatuś powiedziat, że w Łowiczu bardzo ładnie (Dąbrowska 1972, s. 24);

- Strzałków: Wieś. Ho-o, jak to wieś. Bardzo porządna wieś, pastwisko ma zaraz, rzekę (Dąbrowska 1972, s. 18);

- krajobraz: Kawat granatowego perkalu na ścianie byt niebem zimowej nocy. Duze złote pluskiewki tu i tam powtykane - to byly roje gwiazd. Biaty perkal naszyty u dotu przedstawiat śnieżne pole. Na granicy nieba i pola widać było las pod śniegiem i różowe światełka wsi (Dąbrowska 1972, s. 47).

Te dwa typy obrazowania najlepiej oddają kontrast cywilizacyjny między potężną, rozwiniętą przemysłowo i bogatą Anglią a Polską, kojarzoną głównie z małymi, nieznanymi w szerokim świecie miastami (Łowicz) i wsią (Strzałkowo). Nawet przyroda angielska jest ucywilizowana: drzewa rosną w alejach parkowych, rzeka płynie kamiennym korytem, trawniki otoczone są sztachetami, a drzewa rosną na placach. Polska jawi się zaś jako kraj rolniczy, słabo zaludniony i zimny. W Anglii nawet zima jest ciepła i zieleni się trawa: „Drzewa rosły na trawie, która zieleniła się prześlicznie i jaskrawo aż do Bożego Narodzenia co niechże was nie dziwi, gdyż w Anglii zima jest bardzo łagodna" (Dąbrowska 1972, s. 7). 
Lektura opowiadania Marii Dąbrowskiej skłania zatem do refleksji nad tym, jak obecnie młodzi ludzie, którzy całe dotychczasowe życie przeżyli w Wielkiej Brytanii, postrzegają Polskę, od czasu do czasu odwiedzaną wraz z rodzicami. Jako kraj zapóźniony cywilizacyjnie, uboższy, nieinteresujący; czy przeciwnie jako kraj prężnie rozwijający się, z bogatą kulturą i tradycjami? Bardzo wiele zależy zarówno od miejsca zamieszkania, z którego do Anglii przybyli migranci (i do którego przyjeżdżają w odwiedziny ich dzieci), jak i od kapitału kulturowego ich rodzin. Przedstawiona na wykresie 1 struktura migrantów potwierdza utrzymywanie się tendencji uchwyconych w badaniach prowadzonych od początku wzmożonego napływu Polaków do Wielkiej Brytanii. W dalszym ciągu ok. połowy naszych rodaków osiedlających się w Anglii pochodzi ze wsi (16\%) oraz miasteczek i małych miast $(41 \%)^{6}$.

\section{Wykres 1. Struktura migrantów w Wielkiej Brytanii według wielkości miejsca zamieszkania w Polsce przed wyjazdem za granicę}

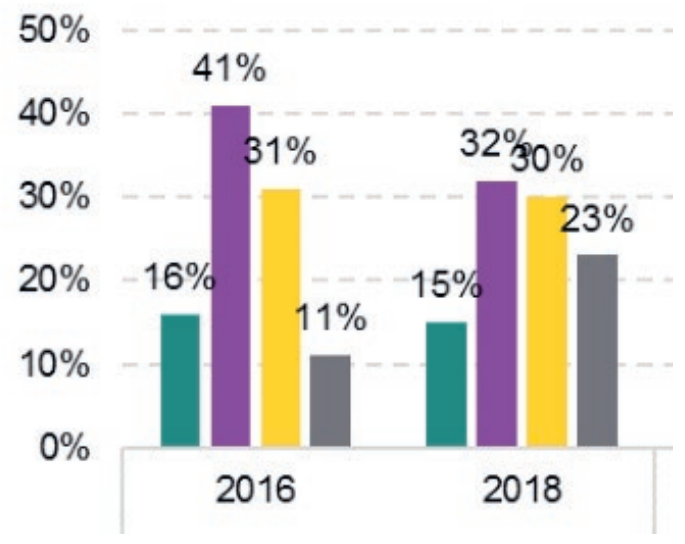

\section{"wieś}

miasto 101-500 tys. mieszkańców
- miasto do 100 tys. mieszkańców miasto 501 tys. lub więcej

Źródło: Chmielewska, Panuciak, Strzelecki 2019, s. 13.

${ }^{6}$ Choć trzeba też zauważyć, że w 2018 r. zarysowało się pewne osłabienie tego trendu, gdyż o 12\% więcej mieszkańców wielkich miast zdecydowało się na wyjazd z Polski do Wielkiej Brytanii. 
Nie można jednoznacznie przesądzać o kapitale kulturowym wszystkich osób przybywających do Zjednoczonego Królestwa z małych miejscowości i wsi. Od lat jednak wyniki badań wskazują, że - ogólnie rzecz biorąc - jest on niższy niż u mieszkańców wielkich miast i zwykle idzie w parze z gorszą sytuacją ekonomiczną (Broszkiewicz 2013). Wprowadzone do dyskursu socjologicznego przez Pierre'a Bourdieu pojęcie kapitału kulturowego zostało rozmaicie zoperacjonalizowane przez wielu badaczy. Tutaj do jego zdefiniowania posłużymy się propozycją Wojciecha Świątkiewicza (2000, s. 35), według którego na kapitał kulturowy osoby składają się: wiedza (wykształcenie), umiejętności (zawód), kompetencje w zakresie komunikacji symbolicznej (werbalnej i niewerbalnej), doświadczanie tradycji kulturowej (zakorzenienie w kulturze), style uczestnictwa w kulturze, zwyczaje i obyczaje, orientacja na wartości, etos (religia, moralność), a także aspiracje życiowe i otwartość na nowe doświadczenia (kierunki mobilności).

To od tych właśnie czynników zależy sposób postrzegania zarówno Polski, jak i Anglii. Bogaty kapitał kulturowy pozwala oderwać się od warunków, stylu życia i tradycji kulturowych ograniczonych wyłącznie do małych ojczyzn oraz najbliższego kręgu rodziny i znajomych należących do tego samego środowiska. Umożliwia także pokonanie poczucia niższości wywołanego przez świadomość deklasacji spowodowanej pracą poniżej własnego (lub rodziców) wykształcenia i kwalifikacji. Orientacja w różnych kodach kulturowych, ustabilizowany system wartości oraz otwarcie na odmienność pozwala migrantowi odpowiednio równoważyć kontrasty między krajem pochodzenia a krajem przyjmującym i uczynić z polskości punkt odniesienia do budowania stabilnej (nie tylko narodowej) tożsamości. Osobom o niskim kapitale kulturowym trudno znaleźć powody do odczuwania dumy narodowej inne niż te, które de facto świadczą o problemach w stosunkach interkulturowych, często mają bowiem uzasadnienie jedynie w korzystnych autostereotypach oraz niesprawiedliwych heterostereotypach obywateli Wielkiej Brytanii oraz migrantów z innych krajów i kręgów kulturowych (por. Lewiński 2014).

Słabość poszczególnych elementów składających się na kapitał kulturowy dzieci migrantów, w tym niedostateczna znajomość polszczyzny, może skutkować jednoznacznym i bezrefleksyjnym przyjęciem tożsamości angielskiej - podobnie jak to się stało w przypadku tytułowego bohatera opowiadania Marii Dąbrowskiej. Marcin Kozera - odcięty całkowicie od kultury polskiej, socjalizowany wyłącznie w środowisku angielskich rówieśników i sąsiadów, kształcony w angielskiej szkole - czuje się Anglikiem, dumnym ze swojej ojczyzny, Anglii:

Ten pyszny pałac to $\mathrm{n}$ a s z parlament, a tu patrz, to $\mathrm{n}$ a s $\mathrm{z}$ najwspanialszy kościół, opactwo westminsterskie. O, patrz! O, patrz! Jaka Anglia jest piękna! Jaki ten Londyn! Patrz, jaki ten Londyn! [...] Ale powiedz sama. Czy to nie jest dumne? Czy to nie jest wspaniałe? Czy w Łowiczu jest taka rzeka? Czy w Łowiczu jest taki pałac? (Dąbrowska 1972, s. 24); 
Pokazywałem Krysi Tamizę i parlament. Chciałem, żeby zobaczyła, jak piękna jest m o j a Anglia (Dąbrowska 1972, s. 35).

Lektura opowiadania Dąbrowskiej może zatem skłonić młodych migrantów do refleksji nad tym, gdzie szukać autentycznych źródeł dumy narodowej, dającej poczucie godności i pewności siebie. Czy można polskość odrzucić jak niepotrzebny balast w imię Cyceroniańskiej formuły ubi bene, ibi patria? Z czego współcześni migranci oraz ich potomkowie mogą być dumni: z Polski czy z Anglii, której dobrobyt budują i dzięki której sami doświadczają dobrobytu? Z biegiem czasu Marcin Kozera, już jako uczeń polskiej szkoły, zadaje sobie pytanie: „Czy miał prawo pysznić się wspaniałością Anglii?” (Dąbrowska 1972, s. 27).

Nie tak dawno w jego angielskiej szkole nauczyciel mówił do chłopców:

- Moi kochani. Na każdym miejscu w tym kraju wasi ojcowie, wasi dziadkowie i ojcowie tych dziadów, aż do początku dziejów Anglii, przelewali krew i oblewali się potem. Pracowali, żyli i umierali na to, żebyście wy mogli być dumni z tych miast i wsi, z piękności, z bogactwa, z potęgi ojczyzny, w której wy znów będzie pracowali.

No to z czegóż, on, Marcin, ma być dumny? Jego dziadowie nie pracowali tu, nie byli tu nawet nigdy (Dąbrowska 1972, s. 27).

Próbę odpowiedzi na to pytanie podjęła Dąbrowska w innym swoim tekście, również przeznaczonym dla młodego odbiorcy. W czytance Nasi ludzie w Westfalii zamieszczonej w jednym z międzywojennych podręczników języka polskiego przedstawiła problem tożsamości narodowej emigrantów, którzy opuścili Polskę „,za chlebem” i osiedlili się w Niemczech. Jako źródło budowania przynależności narodowej i dumy ze swego pochodzenia wskazywała na rosnącą pozycję polityczną i gospodarczą odrodzonej Polski (Rypel 2012, s. 189-190):

Odrodzona Polska ukazała im się jak opiekuńczy, bezpieczny ląd. Będą w niej mieli zawsze oparcie, cokolwiek uczynią i dokądkolwiek podążą. [...] Jedni wrócili do Polski, drudzy zostali i dalej pracują w czarnym westfalskim kraju. Owszem nadpłynęli tam jeszcze i nowi ludzie z Polski. Lecz i ci, i tamci inaczej teraz spoglądają na świat. Mają wolną i potężną Ojczyznę. Znajduje się ona daleko, a jednakże pokrzepia, dodaje sił i otuchy. Zawsze w razie czego jest gdzie powrócić, a w razie krzywdy jest się komu poskarżyć (Tync, Gołąbek 1936, s. 176).

Czy dzisiejsza pozycja polityczna i gospodarcza Polski jest dla współczesnych migrantów oraz ich dzieci powodem do dumy, a może bywa przyczyną zakłopotania, wstydu lub nie ma dla nich znaczenia? Sądząc po wielkiej aktywności wyborczej i masowym udziale emigrantów w wyborach do polskiego parlamentu oraz wyborach prezydenckich organizowanych przez polskie władze w Wielkiej 
Brytanii, chcą mieć oni wpływ na to, co dzieje się w ich ojczyźnie, i nawet jeśli nie zamierzają do niej ostatecznie powrócić, pragną jej dobra, choć zależnie od preferencji politycznych nieco odmiennie je rozumieją.

Marcin Kozera nie stawiałby sobie pytań o to, czy i dlaczego ma być dumny z Polski, gdyby jego ojciec nie podjął decyzji o zapisaniu syna do polskiej popołudniowej szkoły. Ten aspekt opowiadania Dąbrowskiej dotyka bardzo ważnego problemu postaw rodziców wobec podtrzymywania polskości. Dorośli opuszczający ojczyznę (podobnie jak Mateusz Kozera) stanowią pokolenie emigracyjne, a ich dzieci urodzone za granicą (jak Marcin Kozera, Krysia oraz ich koleżanki i koledzy z polskiej szkoły w Londynie) należą do pierwszego pokolenia polonijnego. „Pokolenie emigracyjne jest jeszcze mocno związane ze starym krajem i pod względem językowym i obyczajowym oraz światopoglądowym. Ma często dwie ojczyzny - starą i nową - lub tylko jedną - starą" (Achtelik i in. 2018, s. 30). Dylematy emigrantów przybywających do nowego kraju można sprowadzić do następujących pytań: „Czy wejść w kulturę przyjmującego kraju? Czy utrzymać starą? Czy połączyć elementy obu kultur?” (Wróblewska-Pawlak 2004, s. 155). Rozwiązanie tych rozterek prowadzi do obrania strategii, która może skutkować:

- integracją - czyli spójnym łączeniem elementów obu kultur, prowadzącym do dwujęzyczności i dwukulturowości oraz silnym poczuciem więzi z krajem pochodzenia, które jednocześnie nie stanowi przeszkody w aktywnym i satysfakcjonującym uczestnictwie w nowej wspólnocie;

- asymilacją - polegającą na odrzuceniu kultury ojczystej na rzecz kultury nowego kraju, co przejawia się m.in. nieużywaniem języka polskiego w komunikacji z dziećmi, negatywnymi odczuciami w stosunku do miejsca pochodzenia oraz zrywaniem kontaktów z rodakami;

- separacją - prowadzącą do wyłączenia się z życia społeczno-kulturowego kraju przyjmującego na rzecz trwałego zakotwiczenia mentalnego w kręgu kulturowym języka pierwszego;

- marginalizacją - czyli brakiem identyfikacji z kręgiem kulturowym zarówno kraju pochodzenia, jak i kraju przyjmującego, co skutkuje na ogół słabym opanowaniem języka i kultury rodziców, jak również niepełnym przyswojeniem języka kraju osiedlenia (Achtelik A. i in. 2018).

Strategie te, jak każde tego typu uogólnienia, nie odnoszą się bezpośrednio do losów poszczególnych migrantów ${ }^{7}$. Jak bowiem zaklasyfikować strategię ojca

${ }^{7} \mathrm{Na}$ wybór strategii duży wpływ ma także typ rodzin, w których wychowują się dzieci Polaków mieszkających za granicą - czy są to rodziny polskie, czy mieszane. Tu jednak nie będziemy zajmować się tą kwestią, ponieważ nie jest ona poruszana w omawianym opowiadaniu. Oboje rodzice dziecięcych bohaterów są Polakami. 
Marcina Kozery, który zapisując syna do polskiej szkoły, tak opowiada młodej nauczycielce o losach swojej rodziny:

Matka mu umarła, widzi pani, jak miał dwa lata. Mieszkamy u tutejszych ludzi. Ciągle się jest z Anglikami. Mnie już też jest, powiem pani, ciężko znaleźć słowo, jak chcę mówić po polsku. Ja już trzydzieści lat nie byłem w Polsce. Co pani na to powie? Czy pani kiedy na to przyszło, żeby tak trzydzieści lat być między obcymi? (Dąbrowska 1972, s. 17);

Ja się tam nie boję o zarobki, ani o nic. Za łaską Boską nie powrócę bez grosza [...] Ja mam tam [w Strzałkowie] familię. Jak ja tam powrócę $\mathrm{z}$ takim synem, co nic po naszemu nie umie powiedzieć?

Pani zaśmiała się.

- Ba, trzeba było wcześniej o tym pomyśleć - rzekła (Dąbrowska 1972, s. 18).

Czy stary Kozera, żyjąc 30 lat poza Polską, zasymilował się z angielskim społeczeństwem? Nie nauczył przecież syna mówić po polsku; jego wychowanie powierzył wyłącznie angielskiej szkole, odciął go od kontaktów z innymi Polakami i nie wprowadził ani w polską kulturę, ani w polską tradycję. Nawet rozmawiając z synem lub mówiąc o nim w polskiej szkole, posługiwał się wyłącznie angielszczyzną:

- Niech go pani przyjmie! On się nauczy! On płacze! On płacze!

- Jeszcze do tego płacze! - wykrzyknął pan Mateusz po angielsku (Dąbrowska 1972, s. 17).

Nic więc dziwnego, że Marcin czuł się małym Anglikiem, dumnym ze swojej potężnej ojczyzny, którą kochać nauczono go w szkole. A może Mateusz Kozera przyjął mentalną strategię separacji? Choć żył tak długo poza Polską, to jednak nie włączył się do życia społeczno-kulturowego nowego społeczeństwa obcych, a swą dawną ojczyznę mitologizował jako raj utracony. Z Anglią związany był tylko pracą. Kiedy się dostatecznie wzbogacił, osiągnął swój cel - mógł wrócić do swojej strzałkowskiej Arkadii i tam dopiero żyć w pełni. Wiele wskazuje jednak na to, że ojciec Marcina zintegrował się ze swoim otoczeniem - nauczył się w nim funkcjonować, sprawnie posługiwał się angielszczyzną, dostosował się do reguł rządzących w angielskiej społeczności, inaczej nie mógłby przecież przez tyle lat pracować i dobrze zarabiać, a jednocześnie ciągle jeszcze potrafił mówić dobrze po polsku i czuł się związany z ojczyzną.

Czytając opowiadanie Marii Dąbrowskiej, zwraca się uwagę przede wszystkim na rozterki tożsamościowe przeżywane przez tytułowego bohatera, przedstawiciela pierwszego pokolenia polonijnego, jednak drugoplanowa postać Mateusza Kozery pokazuje równie interesujący aspekt kształtowania się tożsamości ludzi, 
którzy zdecydowali się na opuszczenie własnej ojczyzny i rozpoczęcie życia w nowym kraju. Dzieci współczesnych migrantów mogą zastanowić się nad złożonością i nieoczywistością motywacji, którymi kierowali się ich rodzice, kształtując swój (ale również ich) styl życia Wielkiej Brytanii. Losy pierwszego pokolenia polonijnego są przecież konsekwencją decyzji podejmowanych, często nieświadomie, przez dorosłych. Mateusz Kozera wstydzi się, że syn nie mówi po polsku i obarcza go winą za to, że stał się Anglikiem. Nie dostrzega własnych przewin i nie potrafi pomóc Marcinowi w przejściu przez złożony proces kształtowania własnej tożsamości.

Sekwencja zdarzeń, czy też raczej (nawiązując do tytułu innego dzieła Dąbrowskiej) „przygód człowieka myślącego”, składających się na budowanie tożsamości narodowej Marcina Kozery przedstawia się następująco:

1. nauczycielka w polskiej szkole do ojca Marcina: Tylko to już duży chtopiec, ma ze dwanaście lat. Może woli pozostać Anglikiem? (Dąbrowska 1972, s. 18);

2. Marcin Kozera uczyt się po polsku niby to pilnie, a jednak bez przekonania. Co mu jednym uchem wleciało, to drugim wyleciało, nie zatrzymujac się w sercu (Dąbrowska 1972, s. 19);

3. No cóż, maty Angliku? Oni cię chca zrobić polskim żotnierzem. Cóż Ty na to? [...] Mały Angliku, tak powiedziała, mały Angliku! Styszac te słowa Marcin nie wiedzial, czy go one ubodty, czy go zmartwity, czy może wbity w dumę (Dąbrowska 1972, s. 43);

4. Marcin tobuzowat się i uczyt na przemian, ale pod spodem wesotego życia nurtowaty wcią̇ pytania wcale nietatwe do odpowiedzi. Gniewat sie na to;

5. Ja się tak martwię. Proszę pani, co robić, żeby wiedzieć, kim jestem? Kto ja jestem?;

6. Nauczycielka: Badź dz i e ln y m c z ło wi e ki e m. To wystarczy, żebyś poznat, kim jesteś, kiedy będzie potrzeba. Tylko dzielnym człowiekiem (Dąbrowska 1972, s. 48);

7. Polska jest, proszę pana. Ja jestem Polakiem (Dąbrowska 1972, s. 63);

8. Ja nie umiem dobrze po polsku i mo ge być Anglikiem. I kocham Anglię. Ale mój ojciec jest Polakiem. I ja nie opuszczę Polski [...]. Ja ją kocham. Kocham! (Dąbrowska 1972, s. 63).

Taka była droga Marcina do kształtowania własnej tożsamości narodowej. Dzięki lekturze opowiadania Marii Dąbrowskiej młodzi ludzie należący do pierwszego pokolenia emigrantów mogą przekonać się, że odkrywanie istoty związków z ojczyzną nie jest proste, a niekiedy bywa nawet bolesne. Problem ten może pojawić się nawet wtedy, kiedy czujemy się, tak jak Marcin, całkowicie Anglikiem lub jednoznacznie identyfikujemy się z polskością. Co więcej, 
dziecko dwujęzyczne - początkowo jednakowo blisko związane z dwiema kulturami - w którymś momencie może także odkryć, że bliżej mu do jednej z ojczyzn. Budowanie własnej tożsamości narodowej emigranta czy jego potomka nie jest procesem łatwym i nie przebiega harmonijnie. W jego trakcie toczy się ciągłe negocjowanie znaczeń i przewartościowywanie zjawisk kluczowych dla kultury kraju pochodzenia i kultury kraju, w którym uczeń się wychowuje, zdobywa wykształcenie i poznaje przyjaciół; kraju, z którym wiąże swoją przyszłość.

Marcinowi Kozerze trudne poszukiwanie osobistego związku z ojczyzną rodziców ułatwiła polska szkoła, do której zaczął uczęszczać pod naciskiem ojca. Refleksja nad rolą polskich szkół i stowarzyszeń działających poza granicami naszego kraju to kolejny ważny etap rozważań na marginesie opowiadania Dąbrowskiej. Jest to jednak zagadnienie złożone i należałoby je szerzej omówić na tle postaw rodziców wobec edukacji polonijnej oraz stosunku dzieci i młodzieży do uczęszczania do polskich szkół - co wpływa na osłabienie motywacji, a co ją wzmacnia? Co oferuje współczesna podstawa programowa dla dzieci polskich uczących się za granicą (Rypel 2013, s. 367-376) i jaki obraz ojczyzny przekazują współczesnym młodym Polonusom opracowane dla nich materiały dydaktyczne? Odpowiedzi na te pytania powinny jednak paść w kolejnym artykule.

Choć Marcin Kozera dotyczy rzeczywistości sprzed przeszło stu lat, to jednak może być cenną lekturą dla pierwszego pokolenia polonijnego i młodych migrantów osiadłych nie tylko w Wielkiej Brytanii, lecz także w Niemczech, Holandii, Norwegii, Szwecji, Francji, we Włoszech i w innych jeszcze krajach. Może być dla nich punktem wyjścia do rozważań na temat indywidualnych relacji z krajem pochodzenia i znalezienia własnego sposobu odczuwania tożsamości narodowej. W kształceniu polonijnym potrzebne jest zatem przyzwolenie na możliwość spojrzenia na rodzimą kulturę i historię z perspektywy szerszej niż tylko polska. Takie usytuowanie na zewnątrz jądra polskości pozwala dotrzeć do źródeł zarówno polskich, jak i obcych stereotypów i w konsekwencji stopniowo je przełamywać. Z perspektywy zjawisk innych kultur łatwiej dostrzec i docenić specyfikę kultury polskiej oraz znaleźć w niej swoje miejsce. Claire Kramsch (1995, s. 16) dla nazwania takiej sytuacji bycia pomiędzy dwiema kulturami wprowadziła pojęcie kultury trzeciego miejsca (third place culture). Warto zatem pozwolić, aby młodzi Polacy, którzy żyjąc poza granicami kraju, pragną utrzymywać z nim związki, mogli te związki definiować na różne sposoby, zależnie od osobistej sytuacji każdego z nich. W przeciwnym razie kultura polska oraz język polski, mimo starań rodziców, nauczycieli szkół polonijnych i wielu ludzi dobrej woli działających w rozmaitych stowarzyszeniach, mogą dla młodych emigrantów stać się nie tyle punktem odniesienia, czy może nawet przedmiotem dumy, ile niepotrzebnym i niechcianym balastem. 


\section{Bibliografia}

Achtelik A., Cudak R., Krzyżyk D., Mazur J., Niesporek-Szamburska B., Ożóg K., Pawłowski A., Praszałowicz D., Seretny A., Szul R., Tambor A., Zgółka T. (2018), Nauczanie i promocja języka polskiego w świecie. Diagnoza - stanperspektywy, Katowice.

Bielecki J. (2020), Ilu Polaków mieszka w wielkiej Brytanii. Daleko do miliona, ,Rzeczpospolita”, https:/www.rp.pl/Brexit/312029869-Ilu-Polakowmieszka-w-Wielkiej-Brytanii-Daleko-do-miliona.html.

Broszkiewicz W. (2013), Kapitał kulturowy członków peryferyjnego regionu $w$ ksztattujacym się społeczeństwie informacyjnym. Na przykładzie wyników badań uczniów gimnazjów podkarpackich, „Konteksty Społeczne” t. 1 (2).

Chmielewska I., Panuciak A., Strzelecki P. (2019), Polacy pracujacy za granica w 2018. Raport z badania, Warszawa, Polacy pracujący za granicą w $2018 \mathrm{r}$. Raport z badania, Warszawa, https://www.nbp.pl/publikacje/migracyjne/polacy_pracujacy_za_granica_2018.pdf?fbclid=IwAR1gK_x0QaE461azYn6YMxIxFd0ao_BhZVe8k-eNy3kDm71okQeTmaEvV9o.

Dąbrowska M. (1972), Marcin Kozera. Wilczęta z czarnego podwórza, Warszawa.

Eade J., Drinkwater S., Garapich M.P. (2006), Polscy migranci w Londynieklasa i etniczność, Polskojęzyczne sprawozdanie z badań, tłum. A. Galasińska, M. Łukasiuk, https://www.academia.edu/2856131/Polscy_migranci_w_Londynie_klasa_spo $\%$ C5\%82eczna_i_etniczno $\% \mathrm{C} 5 \% 9 \mathrm{~B} \% \mathrm{C} 4 \% 87$.

Kramsch C. (1995), Contex and Culture in language Teaching, Oxford.

Lewiński P. (2014), Polskie mity i stereotypy, w: Sukcesy, problemy i wyzwania w nauczaniu języka polskiego jako obcego, red. A. Mielczarek, A. Roter-Bourkane, M. Zduniak-Wiktorowicz, Poznań.

Program nauczania ośmioklasowej szkoły podstawowej. Język polski. Klasy V-VIII (1971), Warszawa.

Rypel A. (2012), Edukacyjny wymiar dyskursu edukacyjnego. Na przykładzie podręczników języka polskiego z lat 1918-2010, Bydgoszcz.

Rypel A. (2013), Polska tożsamość narodowa czy etniczna? Rozważania na temat podstawy programowej dla uczniów uczacych się za granica, w: JęzykWielokulturowość - Tożsamość, red. M. Pająkowska, A. Paluszak-Bronka, K. Kołatka, Bydgoszcz.

Szpociński A. (2002), Nowoczesność i ponowoczesność - typy kultur wpisane w podręczniki języka polskiego dla gimnazjów, w: Ocena podręczników gimnazjalnych języka polskiego, red. E. Chałasińska, Warszawa.

Świątkiewicz W. (2000), Wokót socjologicznej koncepcji kapitału kulturowego, w: Kapitat spoteczno-kulturowy a rozwój lokalny i regionalny, red. M.S. Szczepański, Tychy. 
Tync S., Gołąbek J. (1936), Czytanki polskie dla IV klasy szkół powszechnych I stopnia, kurs C, Lwów - Warszawa.

Winnicki Z.J. (2017), Europa Środkowa czy Europa Środkowo-Wschodnia? Europejskie kregi cywilizacyjne, „Wschodnioznawstwo” 11.

Wróblewska-Pawlak K. (2004), Język-tożsamość - imigracja. O strategiach adaptacyjnych Polaków zamieszkatych we Francji w latach osiemdziesiatych $X X$ wieku, Warszawa.

Streszczenie

\section{Moja Polska - moja Anglia. Rozważania na marginesie lektury Marcina Kozery Marii Dąbrowskiej w kontekście współczesnej emigracji do Wielkiej Brytanii}

Problem przedstawiony w artykule dotyczy sytuacji współczesnej polskiej emigracji żyjącej przede wszystkim w Wielkiej Brytanii. Tekst koncentruje się głównie na trudnym procesie odkrywania i kształtowania własnej tożsamości narodowej oraz indywidualnych więzi z Polską i krajem osiedlenia. Punktem wyjścia rozważań jest opowiadanie Marii Dąbrowskiej Marcin Kozera z 1927 r. Kryzys tożsamości głównego bohatera tej opowieści konfrontowany jest ze strategiami budowania własnej tożsamości przez współczesnych młodych emigrantów. Żyją oni zazwyczaj w kulturze trzeciego miejsca, czyli pomiędzy kulturą kraju pochodzenia a kulturą kraju goszczącego. $Z$ tego powodu emigranci mają prawo do indywidualnego, różnorodnego rozumienia i poczucia polskości.

Słowa kluczowe: emigracja, tożsamość narodowa, integracja, asymilacja, separacja, marginalizacja

\section{Summary}

\section{My Poland - my England. Reflections on the reading of Maria Dąbrowska's Marcin Kozera in the context of contemporary emigration to Great Britain}

The problem presented in the article concerns the situation of contemporary Polish emigration living mainly in Great Britain. The text focuses primarily on the difficult process of discovering and shaping one's own national identity and individual ties with Poland and the country of settlement. The starting point for the considerations is Maria Dąbrowska's short story Marcin Kozera from 1927. The identity crisis of the main character of this story is confronted with the strategies of building one's own identity by contemporary young emigrants. They 
usually live in the third place culture, that is, between the culture of the country of origin and the culture of the host country. For this reason, emigrants have the right to an individual, various understanding and feeling of Polishness.

Keywords: emigration, national identity, integration, assimilation, separation, marginalization 